\title{
Use of Systemic Rosmarinus Officinalis to Enhance the Survival of Random-Pattern Skin Flaps
}

\author{
Bilsev İnce ${ }^{1}$, Fatma Bilgen ${ }^{2}$, Ayşe Özlem Gündeşlioğlu ${ }^{1}$, Mehmet Dadac1 ${ }^{1}$, Sümeyye Kozacıoğlu ${ }^{3}$ \\ ${ }^{1}$ Department of Plastic, Reconstructive and Aesthetic Surgery, Necmettin Erbakan University Meram School of Medicine, Konya, Turkey \\ ${ }^{2}$ Plastic, Reconstructive and Aesthetic Surgery Clinic, Elbistan State Hospital, Kahramanmaraş, Turkey. \\ ${ }^{3}$ Department of Pathology, Necmettin Erbakan University Meram School of Medicine, Konya, Turkey
}

Background: Skin flaps are commonly used in softtissue reconstruction; however, necrosis can be a frequent complication. Several systemic and local agents have been used in attempts to improve skin flap survival, but none that can prevent flap necrosis have been identified.

Aims: This study aims to determine whether the use of systemic Rosmarinus officinalis (R. officinalis) extract can prevent flap necrosis and improve skin flap recovery.

Study Design: Animal experimentation.

Methods: Thirty-five Wistar albino rats were divided in five groups. A rectangular random-pattern flaps measuring $8 \times 2 \mathrm{~cm}$ was elevated from the back of each rat. Group I was the control group. In Group II, $0.2 \mathrm{ml}$ of $R$. officinalis oil was given orally $2 \mathrm{~h}$ before surgery. $R$. officinalis oil was then applied orally twice a day for a week. In Group III, $R$. officinalis oil was given orally twice a day for one week before surgery. At the end of the week, $0.2 \mathrm{~mL}$ of R. officinalis oil was given orally $2 \mathrm{~h}$ before surgery. In Group IV, $0.2 \mathrm{~mL}$ of $R$. officinalis oil was injected subcutaneously $2 \mathrm{~h}$ before surgery. After the surgery, $0.2 \mathrm{~mL} R$. officinalis oil was injected subcutaneously twice a day for one week. In Group V, $0.2 \mathrm{~mL} R$. officinalis oil was injected subcutaneously twice a day for one week prior to surgery. At the end of the week, one last $0.2 \mathrm{~mL}$ $R$. officinalis oil injection was administered subcutaneously $2 \mathrm{~h}$ before surgery. After the surgery, $0.2 \mathrm{~mL}$ $R$. officinalis oil was injected subcutaneously twice a day for one week.

Results: The mean percentage of viable surface area was significantly greater $(\mathrm{p}<0.05)$ in Groups II, III, IV, and V as compared to Group I. Mean vessel diameter was significantly greater $(p<0.05)$ in Groups II, III, IV, and V as compared to Group I.

Conclusion: We have determined that, in addition to its anti-inflammatory and anti-oxidant effects, R. officinalis has vasodilatory effects that contribute to increased skin flap survival.

Keywords: Rosmarinus officinalis, flap survivability, tissue defect, rosemary
Skin flaps are commonly used in soft tissue reconstruction; however, necrosis can be a frequent complication. Several systemic and local agents have been used to improve skin flap survival, but none that can prevent flap necrosis has been identified (1-4).

Rosmarinus officinalis (R. officinalis) has been used in the prevention of flap necrosis (5); it is known to exert antimicro- bial (6-10), antioxidant (11-18), anti-inflammatory (19,20), antifungal $(6,9,10)$, antidiabetic $(15)$, anticarcinogenic $(13,19)$, antiplatelet $(21)$, antimetastatic $(13,19)$, antiproliferative (16) and antimutagenic (22) effects.

A previous study investigating the effects of Rosmarinus officinalis on the survival of skin flaps reported that the average ratio of viable surface area to total flap area was $28 \%$

Address for Correspondence: Dr.Bilsev İnce, Department of Plastic, Reconstructive and Aesthetic Surgery, Necmettin Erbakan University Meram School of Medicine, 
in control groups; this value increased to $59 \%$ in groups that were treated with $R$. officinalis extract (5). The viable surface area was further increased to $68 \%$ by topical application of the oil for a week before flap elevation. The authors claimed that in addition to the anti-inflammatory and antioxidant effects, $R$. officinalis had vasodilatory effects that contributed to the increased flap survival.

To further investigate the effects of $R$. officinalis on flap survival, this study investigated whether the systemic administration of $R$. officinalis extract could prevent flap necrosis and improve skin flap recovery.

\section{MATERIALS AND METHODS}

Female Wistar albino rats, 12-14 weeks old and weighing 243-310 g, were used and placed in five groups, each containing seven rats. The experiments were performed in accordance with the guidelines for animal research from the National Institutes of Health and the Committee on Animal Research. The study was approved by Necmettin Erbakan University Meram School of Medicine Ethics Committee. The modified McFarlane rat model was used $(23,24)$. In all groups, the backs of the rats were shaved. For anesthesia, $50 \mathrm{mg} / \mathrm{kg}$ of ketamine hydrochloride (Ketalar vial, Pfizer; İstanbul, Turkey) and $5 \mathrm{mg} / \mathrm{kg}$ of xylazine hydrochloride (Rompun vial, Bayer; Leverkusen, Germany) were intraperitoneally administered before surgery. No dressing was applied after surgery.

Group I was the control group. A rectangular random-pattern flaps measuring $8 \times 2 \mathrm{~cm}$ and including the panniculus carnosus was elevated from the back of each rat. Electrocautery or hemostatic agents were not used to control bleeding. The flaps were then sutured to the location from where they were elevated, and $0.2 \mathrm{~mL}$ of physiological serum was orally administered twice a day for a week.

In Group II, $0.2 \mathrm{~mL}$ of $R$. officinalis oil (Doğa İlaç; İstanbul, Turkey) was orally administered $2 \mathrm{~h}$ before surgery. Subsequently, flaps were elevated and replaced as described for Group I. $R$. officinalis oil was then orally applied twice a day for a week.

In Group III, $R$. officinalis oil was orally administered twice a day for a week before surgery. At the end of the week, 0.2 $\mathrm{mL}$ of $R$. officinalis oil was orally given $2 \mathrm{~h}$ before surgery. Skin flaps were elevated and replaced as described for Group I. R. officinalis oil was orally applied twice a day for a week.

In Group IV, $0.2 \mathrm{~mL}$ of $R$. officinalis oil was subcutaneously injected $2 \mathrm{~h}$ before surgery. Skin flaps were elevated and replaced as described for Group I. After the surgery, $0.2 \mathrm{~mL}$ of $R$. officinalis oil was subcutaneously injected twice a day for a week.

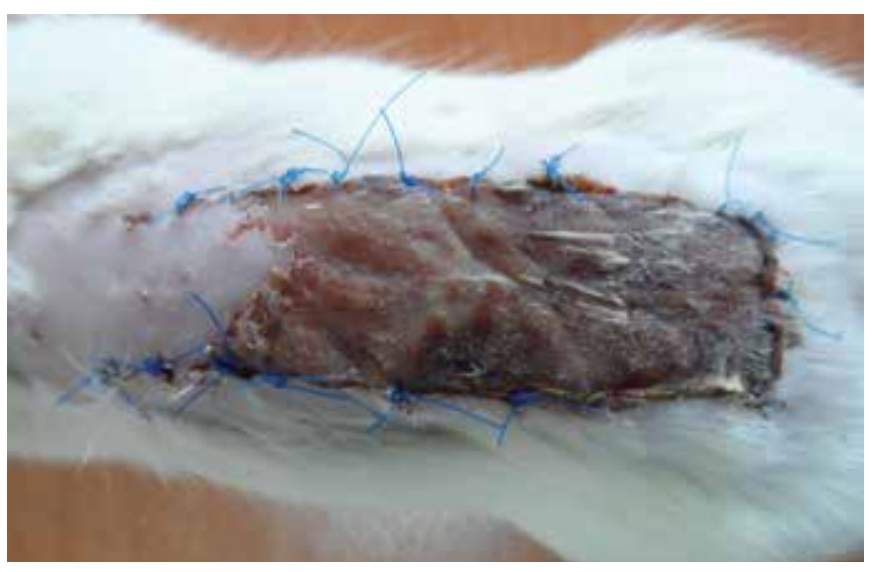

FIG. 1. The flaps in Group I a week after surgery

TABLE 1. Viable and necrotic regions of the flaps and vessel diameters in Group I.

\begin{tabular}{lccccc}
\hline Rat & $\begin{array}{c}\text { Viable areas } \\
\text { of the flaps } \\
\left(\mathrm{cm}^{2}\right)\end{array}$ & $\begin{array}{c}\text { Necrosis } \\
\text { areas of the } \\
\text { flaps }\left(\mathrm{cm}^{2}\right)\end{array}$ & $\begin{array}{c}\text { Viable areas } \\
\text { of the flaps } \\
(\%)\end{array}$ & $\begin{array}{c}\text { Necrosis } \\
\text { areas of the } \\
\text { flaps }(\%)\end{array}$ & $\begin{array}{c}\text { Vessel } \\
\text { diameters } \\
(\mu \mathrm{m})\end{array}$ \\
\hline 1 & 4.26 & 10.74 & 26.62 & 73.38 & 190 \\
2 & 4.22 & 10.78 & 26.37 & 73.63 & 180 \\
3 & 4.24 & 10.76 & 26.50 & 73.50 & 185 \\
4 & 4.23 & 10.77 & 26.43 & 73.57 & 185 \\
5 & 4.27 & 10.73 & 26.68 & 73.32 & 191 \\
6 & 4.25 & 10.75 & 26.56 & 73.44 & 185 \\
7 & 4.21 & 10.79 & 26.31 & 73.69 & 179 \\
Mean & 4.24 & 11.76 & 26.56 & 73.34 & 185 \\
\hline
\end{tabular}

In Group V, $0.2 \mathrm{~mL}$ of $R$. officinalis oil was subcutaneously injected twice a day for a week prior to surgery. At the end of the week, $0.2 \mathrm{~mL}$ of $R$. officinalis oil was subcutaneously injected $2 \mathrm{~h}$ before surgery. Skin flaps were elevated and replaced as described for Group I. After the surgery, $0.2 \mathrm{~mL}$ of $R$. officinalis oil was subcutaneously injected twice a day for a week.

The flaps were evaluated a week after elevation. All images were acquired using the same digital camera, and the viable and necrotic regions were outlined on a transparent paper. The surface area of the viable and necrotic regions was then calculated. To eliminate false-positive results caused by necrosis-induced contraction, only the viable surface area was measured $\left(\mathrm{cm}^{2}\right)$ on the transparent papers using a digital planimeter (Ushikata X-plan 360C+, Yokohama; Kanagawa, Japan). The surface area of the necrotic region was measured by subtracting the viable surface area from the total flap area (16 $\mathrm{cm}^{2}$ ). A biopsy specimen was taken from the viable area of the flap, and specimens were examined under light microscope (Olympus BX 51; Tokyo, Japan). In each group, the diameter of the largest blood vessel in the proximal flap was measured. 


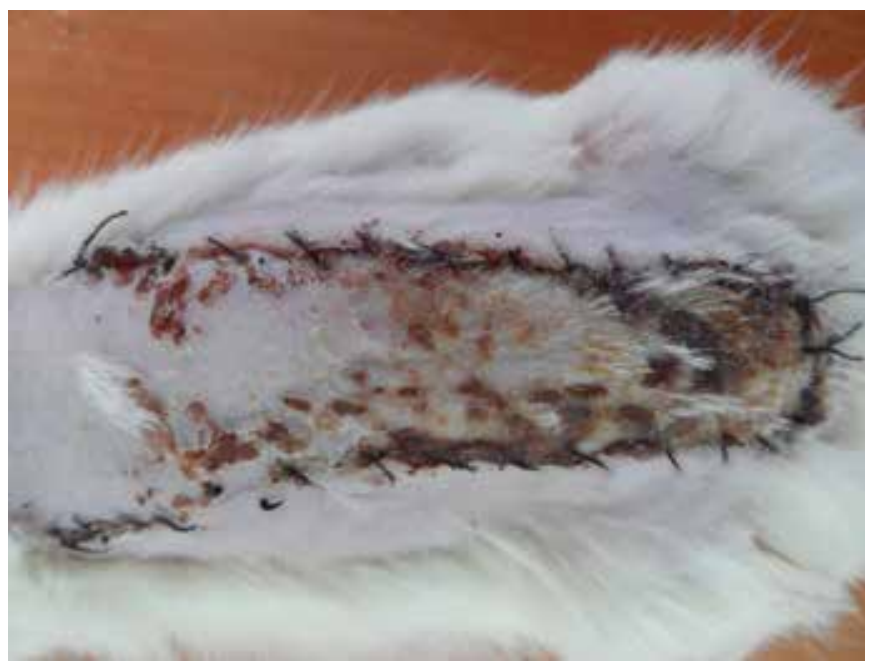

FIG. 2. The flaps in Group II a week after surgery

TABLE 2. Viable and necrotic areas of the flaps in Group II.

\begin{tabular}{lccccc}
\hline Rat & $\begin{array}{c}\text { Viable areas } \\
\text { of the flaps } \\
\left(\mathrm{cm}^{2}\right)\end{array}$ & $\begin{array}{c}\text { Necrosis } \\
\text { areas of the } \\
\text { flaps }\left(\mathrm{cm}^{2}\right)\end{array}$ & $\begin{array}{c}\text { Viable areas } \\
\text { of the flaps } \\
(\%)\end{array}$ & $\begin{array}{c}\text { Necrosis } \\
\text { areas of the } \\
\text { flaps }(\%)\end{array}$ & $\begin{array}{c}\text { Vessel } \\
\text { diameters } \\
(\mu \mathrm{m})\end{array}$ \\
\hline 1 & 5.76 & 10.24 & 36.00 & 64.00 & 185 \\
2 & 9.37 & 6.63 & 58.57 & 41.13 & 200 \\
3 & 9.24 & 6.76 & 57.75 & 42.25 & 200 \\
4 & 12.40 & 3.60 & 77.50 & 22.50 & 220 \\
5 & 8.76 & 7.24 & 54.75 & 45.25 & 195 \\
6 & 8.84 & 7.16 & 55.25 & 44.75 & 195 \\
7 & 10.36 & 5.64 & 64.75 & 35.25 & 205 \\
Mean & 9.09 & 6.94 & 56.63 & 43.37 & 200 \\
\hline
\end{tabular}

\section{Statistical analysis}

Mean values were analyzed using Statistical Package for the Social Sciences version 13.0 for Window (SPSS Corp.; Chicago, IL, USA) statistical software. One-way analysis of variance and Tukey's post hoc test were used to compare the viable surface area and vessel diameter among the groups. $P$ values of $<0.05$ were considered to be statistically significant.

\section{RESULTS}

No rats died during the experiments. No instance of infection was observed.

Measurements for Group I:

A week after flap elevation, the mean ratio of viable surface area to total flap area was $26.56 \% \pm 0.323 \%$ (Figure 1). The mean diameter of the largest vessels in the proximal flap was $185 \pm 6 \mu \mathrm{m}$ (Table 1).

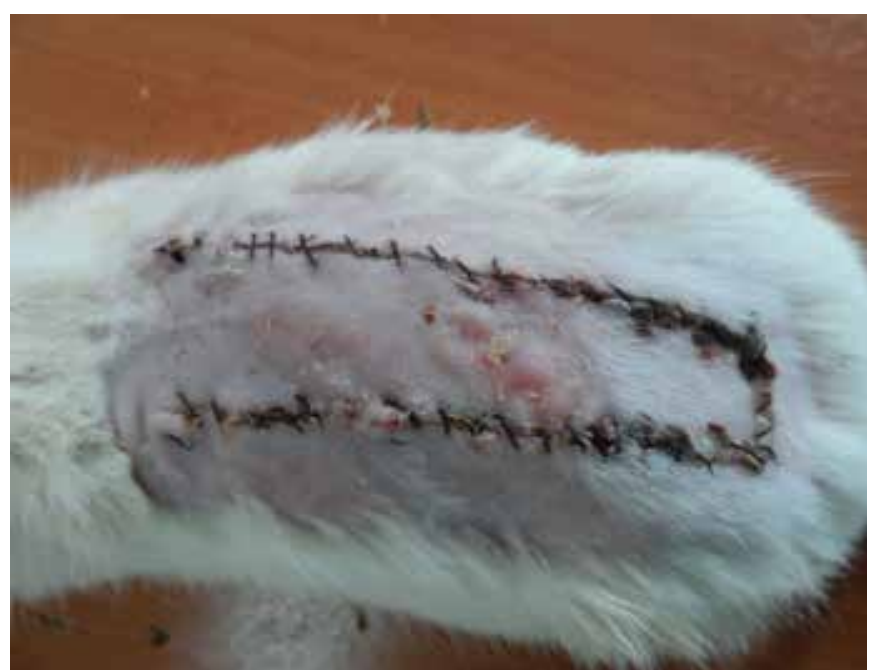

FIG. 3. The flaps in Group III a week after surgery

TABLE 3. Viable and necrotic areas of the flaps in Group III.

\begin{tabular}{lccccc}
\hline Rat & $\begin{array}{c}\text { Viable areas } \\
\text { of the flaps } \\
\left(\mathrm{cm}^{2}\right)\end{array}$ & $\begin{array}{c}\text { Necrosis } \\
\text { areas of the } \\
\text { flaps }\left(\mathrm{cm}^{2}\right)\end{array}$ & $\begin{array}{c}\text { Viable areas } \\
\text { of the flaps } \\
(\%)\end{array}$ & $\begin{array}{c}\text { Necrosis } \\
\text { areas of the } \\
\text { flaps }(\%)\end{array}$ & $\begin{array}{c}\text { Vessel } \\
\text { diameters } \\
(\mu \mathrm{m})\end{array}$ \\
\hline 1 & 15.68 & 4.32 & 98 & 2 & 260 \\
2 & 15.80 & 0.20 & 98.75 & 1.25 & 265 \\
3 & 15.77 & 0.23 & 98.56 & 1.44 & 255 \\
4 & 15.83 & 0.17 & 98.93 & 1.07 & 265 \\
5 & 13.90 & 2.10 & 86.87 & 13.13 & 225 \\
6 & 15.88 & 0.12 & 99.25 & 0.75 & 270 \\
7 & 14.70 & 1.30 & 91.87 & 8.13 & 230 \\
Mean & 15.38 & 0.62 & 96.12 & 3.88 & 252.8 \\
\hline
\end{tabular}

Measurements for Group II:

A week after flap elevation, the mean ratio of viable surface area to total flap area was $56.63 \% \pm 1.298 \%$ (Figure 2). The mean diameter of the largest vessels in the proximal flap was $200 \pm 20 \mu \mathrm{m}$ (Table 2).

Measurements for Group III:

A week after flap elevation, the mean ratio of viable surface area to total flap area was $96.12 \% \pm 2.102 \%$ (Figure 3). The mean diameter of the largest vessels in the proximal flap was $252 \pm 18 \mu \mathrm{m}$ (Table 3 ).

Measurements for Group IV:

A week after flap elevation, the mean ratio of viable surface area to total flap area was $56.38 \% \pm 1.299 \%$ (Figure 4). The mean diameter of the largest vessels in the proximal flap was $198 \pm 18 \mu \mathrm{m}$ (Table 4).

Measurements for Group V:

A week after flap elevation, the mean ratio of viable surface area to total flap area was $57.06 \% \pm 1.027 \%$ (Figure 5). The mean diameter of the largest vessels in the proximal flap was $202 \pm 18 \mu \mathrm{m}$ (Table 5). 


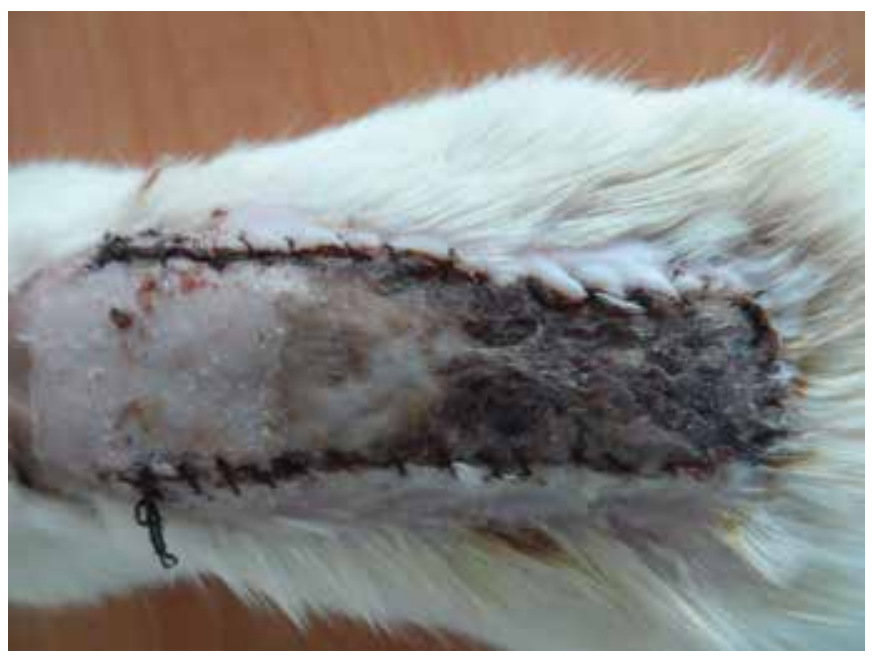

FIG. 4. The flaps in Group IV a week after surgery

TABLE 4. Viable and necrotic areas of the flaps in Group IV.

\begin{tabular}{lccccc}
\hline Rat & $\begin{array}{c}\text { Viable areas } \\
\text { of the flaps } \\
\left(\mathrm{cm}^{2}\right)\end{array}$ & $\begin{array}{c}\text { Necrosis } \\
\text { areas of the } \\
\text { flaps }\left(\mathrm{cm}^{2}\right)\end{array}$ & $\begin{array}{c}\text { Viable areas } \\
\text { of the flaps } \\
(\%)\end{array}$ & $\begin{array}{c}\text { Necrosis } \\
\text { areas of the } \\
\text { flaps }(\%)\end{array}$ & $\begin{array}{c}\text { Vessel } \\
\text { diameters } \\
(\mu \mathrm{m})\end{array}$ \\
\hline 1 & 5.76 & 10.24 & 36.00 & 64.00 & 185 \\
2 & 9.37 & 6.63 & 58.57 & 41.13 & 200 \\
3 & 9.24 & 6.76 & 57.75 & 42.25 & 200 \\
4 & 12.40 & 3.60 & 77.50 & 22.50 & 220 \\
5 & 8.76 & 7.24 & 54.75 & 45.25 & 195 \\
6 & 8.84 & 7.16 & 55.25 & 44.75 & 195 \\
7 & 10.36 & 5.64 & 64.75 & 35.25 & 205 \\
Mean & 9.09 & 6.94 & 56.63 & 43.37 & 200 \\
\hline
\end{tabular}

The mean percentage of viable surface area was significantly greater $(p<0.05)$ in Groups II, III, IV, and V than in Group I, and it was significantly greater in Group III than in Groups II, IV, and V $(\mathrm{p}<0.05)$. The mean vessel diameter was significantly greater $(p<0.05)$ in groups II, III, IV, and V than that in Group I, and it was significantly greater in Group III than in groups II, IV, and V $(\mathrm{p}<0.05)$ (Figure 6).

\section{DISCUSSION}

This study demonstrated that the viable surface area of $R$. officinalis-treated flaps was significantly greater in all treated groups as compared to control group. The oral administration of the oil for a week before surgery resulted in the greatest increase in flap survival (96\%; Group III), and this group also showed the largest blood vessel diameters. We have therefore determined that in addition to its anti-inflammatory and antioxidant effects, $R$. officinalis has vasodilatory effects that contribute to increased skin flap survival.

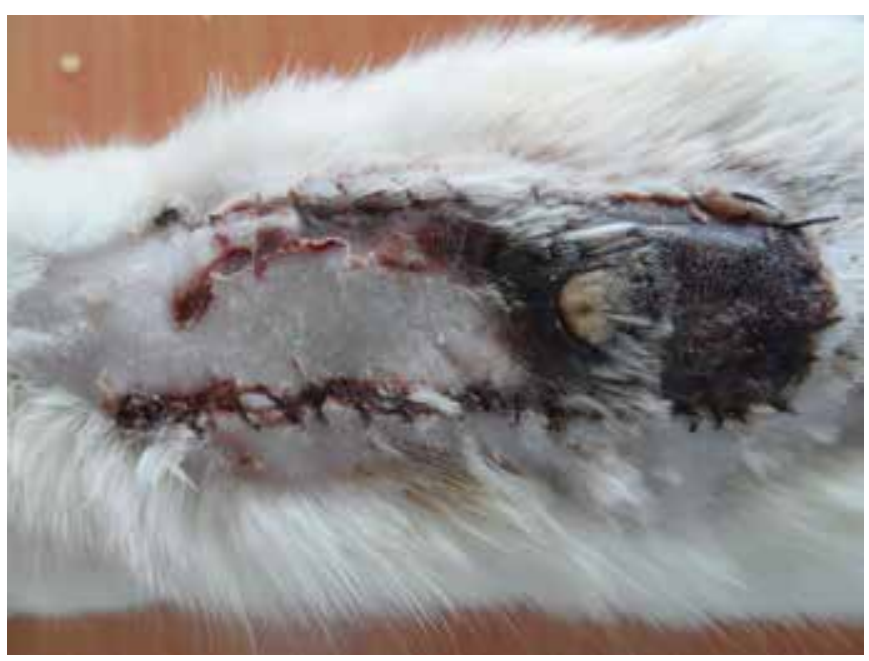

FIG. 5. The flaps in Group V a week after surgery

TABLE 5. Viable and necrotic areas of the flaps in Group V.

\begin{tabular}{lccccc}
\hline Rat & $\begin{array}{c}\text { Viable areas } \\
\text { of the flaps } \\
\left(\mathrm{cm}^{2}\right)\end{array}$ & $\begin{array}{c}\text { Necrosis } \\
\text { areas of the } \\
\text { flaps }\left(\mathrm{cm}^{2}\right)\end{array}$ & $\begin{array}{c}\text { Viable areas } \\
\text { of the flaps } \\
(\%)\end{array}$ & $\begin{array}{c}\text { Necrosis } \\
\text { areas of the } \\
\text { flaps }(\%)\end{array}$ & $\begin{array}{c}\text { Vessel } \\
\text { diameters } \\
(\mu \mathrm{m})\end{array}$ \\
\hline 1 & 5.14 & 10.86 & 32.12 & 67.87 & 185 \\
2 & 10.55 & 5.45 & 65.94 & 34.06 & 205 \\
3 & 5.81 & 9.19 & 36.31 & 63.69 & 190 \\
4 & 11.19 & 4.81 & 69.94 & 30.06 & 210 \\
5 & 12.45 & 3.55 & 78.99 & 22.01 & 220 \\
6 & 10.49 & 5.51 & 65.57 & 34.43 & 205 \\
7 & 8.42 & 7.58 & 52.63 & 47.37 & 200 \\
Mean & 9.13 & 6.87 & 57.06 & 42.93 & 202.14 \\
\hline
\end{tabular}

Random-pattern skin flaps are widely used in plastic surgery. Although they are technically simple, flap necrosis can be seen as a complication. When flaps become necrotic, undesired complications such as additional surgical procedures, increased length of hospital stay and increased treatment costs are incurred. Thus, improving the survival of random-pattern skin flaps is an important goal in clinical practice (1-4).

There are several drugs that improve circulation in skin flaps. These may reduce the viscosity of the blood and increase the flexibility of erythrocytes. They may be axon blockers, alpha receptor blockers, or smooth muscle relaxants. Anti-inflammatory drugs and antioxidants have also been used to reduce the cellular effects of ischemia $(25,26)$. The sequelae of these substances on flap viability rates vary between $68 \%$ and $83 \%$. In our study, when $R$. officinalis was orally administered for a week before surgery, the flap survival rate increased to $96 \%$. In comparison, the highest flap viability rate found in previous literature was $83 \%$ (25). In that study, the skin flap was $11 \times 3 \mathrm{~cm}$ in size, and the average ratio of the viable surface area to the total flap area in the control group was $59 \%$. 

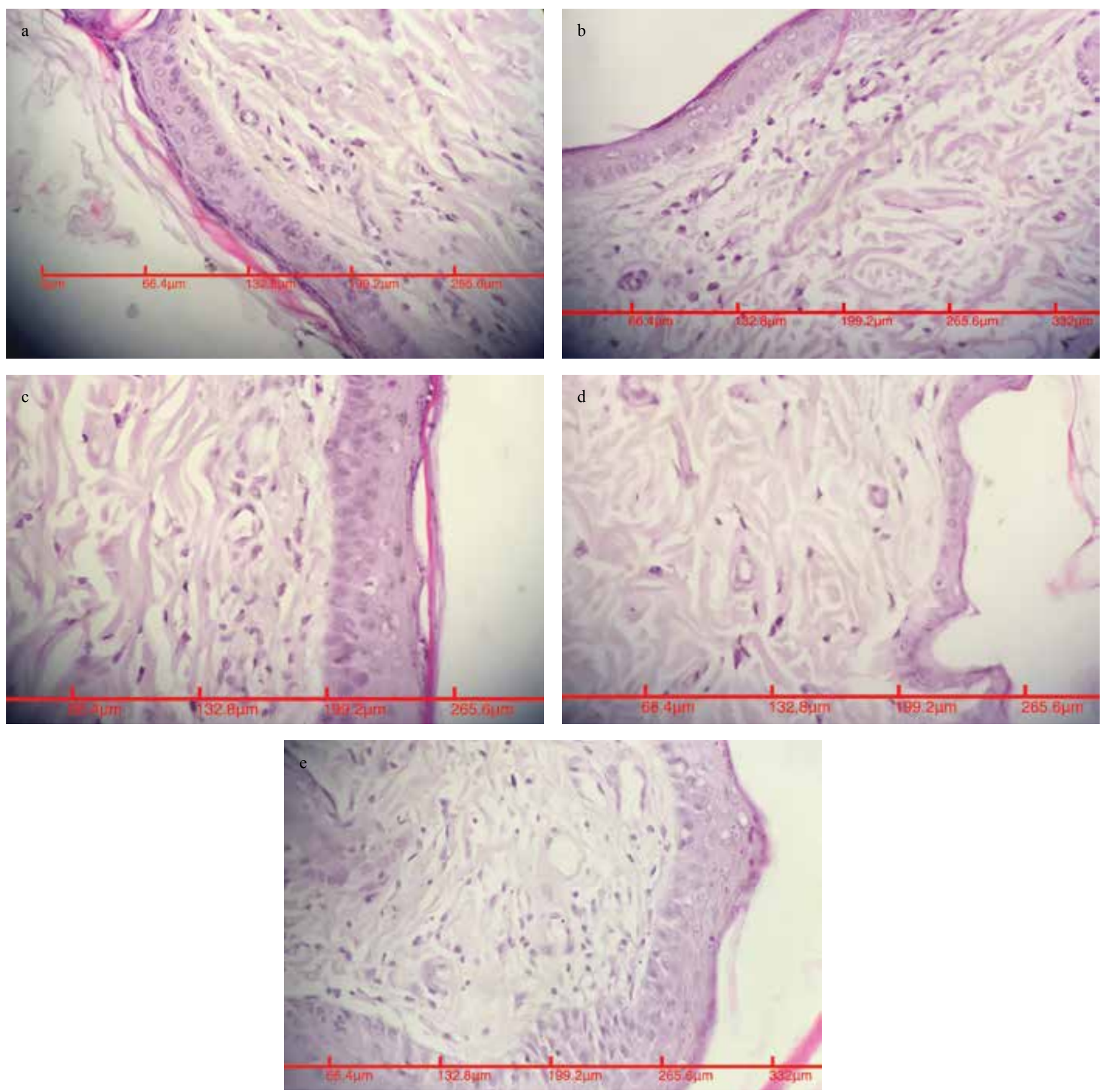

FIG. 6. a-e. $x 400, H \& E$; appearance of largest blood vessels in the proximal flap in Group I (a). x400, H\&E; appearance of largest blood vessels in the proximal flap in Group II (b). x400, H\&E; appearance of largest blood vessels in the proximal flap in Group III (c). x400, H\&E; appearance of largest blood vessels in the proximal flap in Group IV (d). x400, H\&E; appearance of largest blood vessels in the proximal flap in Group V (e)

The average ratio of viable surface area to total flap area was found to be highest in a study investigating the effects of the subdermal use of vascular endothelial growth factor (VEGF) on flap viability (27). The effect of VEGF on skin flap survival was studied in a rat transverse rectus abdominis musculocutaneous flap using a $3 \times 8 \mathrm{~cm}$ skin paddle with the inferior epigastric vessels. VEGF was injected into the subcutaneous fascial layer in the area where the flap would be dissected, and the flap was then raised 7 days after injection. In this study, the average ratio of the viable surface area increased from $28 \%$ to $76 \%$ in the experimental group. This rate is lower than that in Group III, where a systemic dose of the $R$. officinalis oil for a week before surgery was administered. 
While the average ratio of viable to necrotic surface area in control groups was $28 \%$ in the previous study on R. officinalis, this value was $27 \%$ in our study (5). Although our control group had lower success than previous studies, in our Group III, the viable surface area was greater. When both studies are considered together, we suggest that the bioavailability of $R$. officinalis is the greatest when orally administered.

In a previous study conducted to determine the safe dose rate of $R$. officinalis, $\leq 2 \mathrm{mg} / \mathrm{kg}$ was concluded to be safe for rats (28). With reference to this finding, we did not exceed this level in our study.

The proportions of the basic components of $R$. officinalis vary among genotypes. These components and their proportions are as follows: alpha-pinene (7.3-37.8\%), kampen $(0-12.1 \%)$, myrcene $(0-6.6 \%)$, simolin $(0-4.5 \%)$, limonene (0-7.2\%), 1.8 cineol (13.6-67.3\%), kamper (2.2-48.3\%), and borneol (1.3-12.7\%) (29). The rosemary oil used in the present study was obtained from rosemary plants grown in the Çukurova region (southern Anatolia). Although the genotype of this oil was not determined, it was believed to be the Kozan genotype, which is the most commonly found genotype in the region. The Kozan genotype contains alpha-pinene (13.5\%), camphene $(4.1 \%)$, mirsene $(2.2 \%)$, simole $(2.8 \%)$, limonene (2.4\%), camphere $(2.2 \%)$, bornele $(5.3 \%)$, and 1.8 cineol $(67.3 \%)$ and may be termed as the 1.8 cineol genotype because it contains the highest content of 1.8 cineol among other genotypes (29).

A previous study identified hesperetin, acacetin, diosmetin, ferulic acid, apigenin, luteolin, rosmarinic acid and caffeic acid as the active components in $R$. officinalis via capillary electrophoresis (30). R. officinalis oil was used as an oral and subcutaneous agent in our study. Although both applications of the oil increased skin flap survival, we did not determine the specific component responsible for the improvement. Further studies are required to clarify these effects.

The primary measure involved in preventing flap necrosis is increased blood circulation to the flap. Following our findings that $R$. officinalis significantly decreases the rate of flap necrosis, we suggest that this treatment is useful in patients with circulatory system problems and as an alternative therapy to increase blood circulation in flaps.

Furthermore, the antioxidant, antiproliferative, anti-inflammatory, and vasodilatory effects of $R$. officinalis may be useful in patients with chronic obliterative artery disease because of the compound's ability to increase blood flow and to serve as a prophylactic and therapeutic agent for diabetes-induced ulcers because of its antidiabetic, antimicrobial, and vasodilatory effects. This study demonstrated that $R$. officinalis can help prevent flap necrosis; however, further clinical studies are required.
Ethics Committee Approval: Ethics committee for this study was received from the ethics committee of Necmettin Erbakan University Meram School of Medicine.

\section{Informed Consent: N/A.}

Peer-review: Externally peer-reviewed.

Author contributions: Concept - B.İ.; Design - B.İ.; Supervision B.İ., M.D.; Resource - B.İ., F.B.; Materials - B.İ., F.B., S.K.; Data Collection and/or Processing - F.B., S.K.; Analysis and/or Interpretation - B.İ., F.B., A.Ö.G.; Literature Search - B.İ., F.B.; Writing - B.İ., F.B.; Critical Reviews - B.İ., A.Ö.G., M.D.

Acknowledgements: The authors thank Mehmet Uyar, MD for his statistical analysis support.

Conflict of Interest: No conflict of interest was declared by the authors.

Financial Disclosure: The authors declared that this study has received no financial support.

\section{REFERENCES}

1. Smith JD, Pribaz JJ. Flaps. In: Plastic surgery indications, operations and outcomes. Achauer BM, Eriksson E, Wilkins EG, Vandekam VM editors. 2nd ed. St. Louis-Missouri: Mosby, 2000; 1: 261-90.

2. Karacaoglu E, Yuksel F, Turan SO, Zienowicz RJ. Chemical delay: an alternative to surgical delay experimental study. Ann Plast Surg 2002;49:73-80. [CrossRef]

3. Kose R, Yildirim AM, Okur MI, Tugrul I. The effects of $\mathrm{N} \omega$-nitro -L-arginine (L-NNA) on blood pressure and survival of the skin flaps in rats. Turk Plast Surg 2010;18:610.

4. Demirel M, Heper AO, Yormuk E. Comparison of pharmacologic delay operation by local VEGF injection with other surgical delay procedures on rat dorsal skin flap. Turk Plast Surg 2010;18:24-30.

5. Ince B, Yildirim AM, Okur MI, Dadaci M, Yoruk E. Effects of Rosmarinus officinalis on the survivability of random-patterned skin flaps: an experimental study. J Plast Surg Hand Surg 2015;49:83-7. [CrossRef]

6. Angioni A, Barra A, Cereti E, Barile D, Coïsson JD, Arlorio M, et al. Chemical composition, plant genetic differences, antimicrobial and antifungal activity investigation of the essential oil of Rosmarinus officinalis L. J Agric Food Chem 2004;52:35305. [CrossRef]

7. Bozin B, Mimica N, Samojlik I, Jovin E. Antimicrobial and antioxidant properties of rosemary and sage (Rosmarinus officinalis L. and Salvia officinalis L, Lamiaceae) essential oils. J Agric Food Chem 2007;55:7879-85. [CrossRef] 
8. Fu Y, Zu Y, Chen L, Efferth T, Liang H, Liu Z. Investigation of antibacterial activity of rosemary essential oil against Propionibacterium acnes with atomic force microscopy. Planta Med 2007:1275-80. [CrossRef]

9. Luqman S, Dwivedi GR, Darokar MP, Kalra A, Khanuja SP. Potential of rosemary oil to be used in drug-resistant infections. Altern Ther Health Med 2007;13:54-9.

10. van Vuuren SF, Suliman S, Viljoen AM. The antimicrobial activity of four commercial essential oils in combination with conventional antimicrobials. Lett Appl Microbiol 2009;48:440-6. [CrossRef]

11. Siurin SA. Effects of essential oil on lipid peroxidation and lipid metabolism in patients with chronic bronchitis. Klin Med (Mosk) 1997;75:43-5.

12. Bhale SD, Xu Z, Prinyawiwatkul W, King JM, Godber JS. Oregano and rosemary extracts inhibit oxidation of long-chain n-3 fatty acids in menhaden oil. J Food Sci 2007;72:504-8. [CrossRef]

13. Huang HC, Huang CY, Lin-Shiau SY, Lin JK. Ursolic acid inhibits IL-1beta or TNF-alpha-induced C6 glioma invasion through suppressing the association ZIP/p62 with PKC-zeta and downregulating the MMP-9 expression. Mol Carcinog 2009;48:51731. [CrossRef]

14. Posadas SJ, Caz V, Largo C, De la Gándara B, Matallanas B, Reglero G, et al. Protective effect of supercritical fluid rosemary extract, Rosmarinus officinalis, on antioxidants of major organs of aged rats. Exp Gerontol 2009;44:383-9. [CrossRef]

15. Bakirel T, Bakirel U, Keles OU, Ulgen SG, Yardibi H. In vivo assessment of antidiyabetic and antioxidant activities of rosemary (Rosmarinus Officinalis) in alloxan-diyabetic rabbits. $J$ Ethnopharmacol 2008;116:64-73. [CrossRef]

16. Cheung S, Tai J. Anti-proliferative and antioxidant properties of rosemary Rosmarinus officinalis. Oncol Rep 2007;17:1525-31. [CrossRef]

17. Almela L, Sánchez MB, Fernández JA, Roca MJ, Rabe V. Liquid chromatograpic-mass spectrometric analysis of phenolics and free radical scavenging activity of rosemary extract from different raw material. J Chromatogr A 2006;1120:221-9. [CrossRef]

18. D'Evoli L, Huikko L, Lampi AM, Lucarini M, Lombardi-Boccia G, Nicoli S, et al. Influence of rosemary (Rosmarinus officinalis, L.) on plant sterol oxidation in extra virgin olive oil. $\mathrm{Mol}$ Nutr Food Res 2006;50:818-23. [CrossRef]
19. Peng CH, Su JD, Chyau CC, Sung TY, Ho SS, Peng CC, et al. Supercritical fluid extracts of rosemary leaves exhibit potent anti-inflammation and anti-tumor effects. Biosci Biotechnol Biochem 2007;71:2223-32. [CrossRef]

20. Takaki I, Bersani LE, Vendruscolo A, Sartoretto SM, Diniz SP, Bersani-Amado CA, et al. Anti-inflammatory and antinociceptive effects of Rosmarinus officinalis L. essential oil in experimental animal models. J Med Food 2008;11:741-6. [CrossRef]

21. Lee JJ, Jin YR, Lee JH, Yu JY, Han XH, Oh KW, et al. Antiplatelet activity of carnosic acid, a phenolic diterpene from Rosmarinus officinalis. Planta Med 2007;73:121-7. [CrossRef]

22. Sylianco CYL, Jocano AP, Lim CM. Antimutagenicity of twenty Philippine plants using the micronucleus test in mice. Philipp $J$ Sci 1988;117:231-35.

23. Mcfarlane RM, Deyoung G, Henry RA. The design of a pedicle flap in the rat to study necrosis and its prevention. Plast Reconstr Surg 1965;35:177-82. [CrossRef]

24. Matsumura H, Yoshizawa N, Vedder NB, Watanabe K. Preconditioning of the distal portion of a rat random-pattern skin flap. Br J Plast Surg 2001;54:58-61. [CrossRef]

25. Hosnuter M, Babuccu O, Kargi E, Altinyazar C. Dual preconditioning: effects of pharmacological plus ischemic preconditioning on skin flap survival. Ann Plast Surg 2003;50:398-402. [CrossRef]

26. Kim HJ, Xu L, Chang KC, Shin SC, Chung J, Kang D, et al. Anti-inflammatory effects of anthocyanins from black soybean seed coat on the keratinocytes and ischemia-reperfusion injury in rat skin flaps. Microsurgery 2012;32:563-70. [CrossRef]

27. Zhang F, Fischer K, Komorowska-Timek E, Guo M, Cui D, Dorsett-Martin W, et al. Improvement of skin paddle survival by applicationof vascular endothelial growth factor in a rat tram flap model. Ann Plast Surg 2001;46:314-9. [CrossRef]

28. Anadón A, Martínez-Larra-aga MR, Martínez MA, Ares I, García-Risco MR, Señoráns FJ, et al. Acute oral safety study of rosemary extracts in rats. J Food Prot 2008;71:790-5.

29. Kırpık M. Çukurova bölgesi kıraç ve taban arazi koşullarında yetiştirilen biberiye (Rosmarinus officinalis L.) çeşitlerinin verim kalitesi üzerine araştırmalar [Doktora Tezi]. Adana: Çukurova Üniversitesi Fen Bilimleri Enstitüsü, Tarla Bitkileri Anabilim Dal1, 2005.

30. Peng Y, Yuan J, Liu F, Ye J. Determination of active components in rosemary by capillary electrophoresis with electrochemical detection. J Pharm Biomed Anal 2005;39:431-7. [CrossRef] 